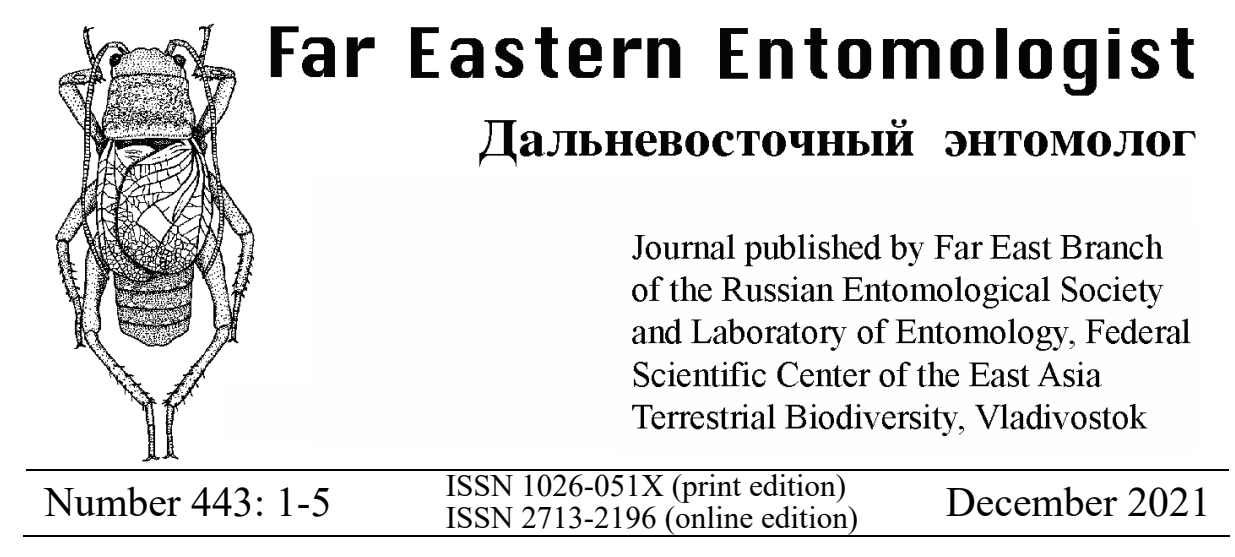

https://doi.org/10.25221/fee.443.1

http://zoobank.org/References/7659DDE5-4032-48E6-AF91-363F7912449F

\title{
TWO NEW FOR RUSSIA GEOMETRID MOTHS (LEPIDOPTERA: GEOMETRIDAE) FROM PRIMORSKY KRAI: RECENT IMMIGRANTS OR RARE SPECIES?
}

\section{E. A. Beljaev}

Federal Scientific Center of the East Asia Terrestrial Biodiversity, Far East Branch of the Russian Academy of Sciences, Vladivostok,690022,Russia.E-mail: beljaev@biosoil.ru

Summary. Two East Asian geometrid moths, Paratrichopteryx misera (Butler, 1879) and Rheumaptera hecate hecate (Butler, 1878), are recorded from Russia for the first time. Their invasive or native status in the south part of Primorsky Krai is briefly discussed. East.

Key words: Lepidoptera, Geometridae, fauna, new record, invasion, Russian Far

Е. А. Беляев. Две новые для России пяденицы (Lepidoptera: Geometridae: Larentiinae) из Приморского края: недавние вселенцы или редкие виды? // Дальневосточный энтомолог. 2021. N 443. С. 1-5.

Резюме. Впервые в России обнаружены две восточноазиатские пяденицы, Paratrichopteryx misera (Butler, 1879) и Rheumaptera hecate hecate (Butler, 1878). Кратко обсуждается их инвазивный или местный статус на юге Приморского края.

\section{INTRODUCTION}

The Khasan District in Primorsky Krai (Russia) borders with North Korea and Northeast China. It is territory with most warm winter condition on the continental 
part of the Russian Far East, wherefore a number of southern species of plants and animals have northern limit of their areas here. From time to time new southern species are found in Khasan District. They could penetrate into Russia as accidental bringing of single specimens with typhoons, or as result of invasion in accordance with the current trend of the global warming. Dubatolov (2021), Koshkin et al. (2021) and Ustjuzhanin et al. (2021) reviewed of those invasions of moths. Among the geometrid moths only 14 species are so far unknown to the north of Khasan District: Alsophila vladimiri Viidalepp, 1986, Callabraxas fabiolaria (Oberthür, 1884), Dysstroma cinereata (Moore, 1867), Episteira nigrilinearia (Leech, 1897), Hemistola tenuilinea (Alphéraky, 1897), Heterothera postalbida (Wileman, 1911), Idaea trisetata (Prout, 1922), Idiotephria amelia (Butler, 1878), Luxiaria amasa (Butler, 1878), Maxates fuscofrons (Inoue, 1954), Megabiston plumosaria (Leech, 1891), Operophtera japonaria (Leech, 1891), Thinopteryx crocoptera (Kollar, 1844), and Xanthorhoe saturata (Guenée, 1957 [1858]) (Beljaev, 2016). Herein, two more taxa are added to them and their invasive or native status is discussed.

\section{NEW RECORDS}

Family Geometridae

\section{Subfamily Larentiinae}

\section{Paratrichopteryx misera (Butler, 1879)}

Figs 1, 2

Lobophora misera Butler, 1879: 443. Type locality: Yokohama, Japan.

MATERIAL EXAMINED. Russia: Primorsky Krai, Khasan District, $13 \mathrm{~km}$ SW Slavyanka, Ryazanovka, 4247'37"N, 131¹5'08"E, on light, 15.V 1987, 1 , E.A. Beljaev leg.; $34 \mathrm{~km} \mathrm{SSW} \mathrm{of} \mathrm{Slavyanka,} \mathrm{western} \mathrm{slopes} \mathrm{of} \mathrm{Gamov} \mathrm{Peninsula,}$ Vityaz, 42 $35^{\prime} 57^{\prime \prime} \mathrm{N}, 131^{\circ} 11^{\prime} 14^{\prime \prime} \mathrm{E}$, on light, 17.V 2021, 19, Yu. Tshistjakov leg.

DISTRIBUTION. Russia (first record), Japan (Hokkaido, Honshu) (Nakajima \& Yazaki, 2011), South Korea (Choi, 2007).

REMARKS. P. misera is rare species known from the Korean Peninsula only from most northern part of South Korea (Choi, 2007; Kim et al., 2016), on the distance about $600 \mathrm{~km} \mathrm{SW}$ from new localities in Russia. In Japan it also is rare species with local and limited distribution (Nakajima \&Yazaki, 2011). In North Korea this species has not been found yet. In Japan larvae feed on different Quercus (Fagaceae) including $Q$. dentata (Hashimoto, 2021), which is also common in the Khasan District of Russia.

\section{Rheumaptera hecate hecate (Butler, 1878)}

Figs 3, 4

Melanippe hecate Butler, 1878: 448. Type locality: Yokohama, Japan.

MATERIAL EXAMINED. Russia: Primorsky Krai, Khasan District, 22 km SW of Slavyanka, Sukhanovsky Ridge, upper Gladkaya River, 42 $47^{\prime} 52^{\prime \prime}$ N, $131^{\circ} 08^{\prime} 12^{\prime \prime}$ E, 
oak-rhododendron woodland, at day time, 10.VI 1987, 1ðð, E.A. Beljaev leg.; 16 km WSW Slavyanka, middle Ryazanovka River, 42 ${ }^{\circ} 50^{\prime} 35^{\prime \prime N}, 131^{\circ} 11^{\prime} 05^{\prime \prime E}$, at day time, 11.VI 1989, 1 ${ }^{\lambda}$, E. Beljaev leg.; $36 \mathrm{~km} \mathrm{SW}$ of Slavyanka, eastern slopes of Gamov Peninsula, Telyakovsky Bay, $42^{\circ} 34^{\prime}$ N, $131^{\circ} 12^{\prime}$ E, oak-rhododendron woodland, on light, 15-16.VI 2003, 3ð, 3 , E. Beljaev leg.; 34 km SW of Slavyanka, western slopes of Gamov Peninsula, Vityaz, 42 $35^{\prime} 57^{\prime \prime} \mathrm{N}, 131^{\circ} 11^{\prime} 14^{\prime \prime} \mathrm{E}$, on the flowers of Arabis (Brassicaceae), 6.VI 2004, 1 ㅇ, M. Proshchalykin leg.

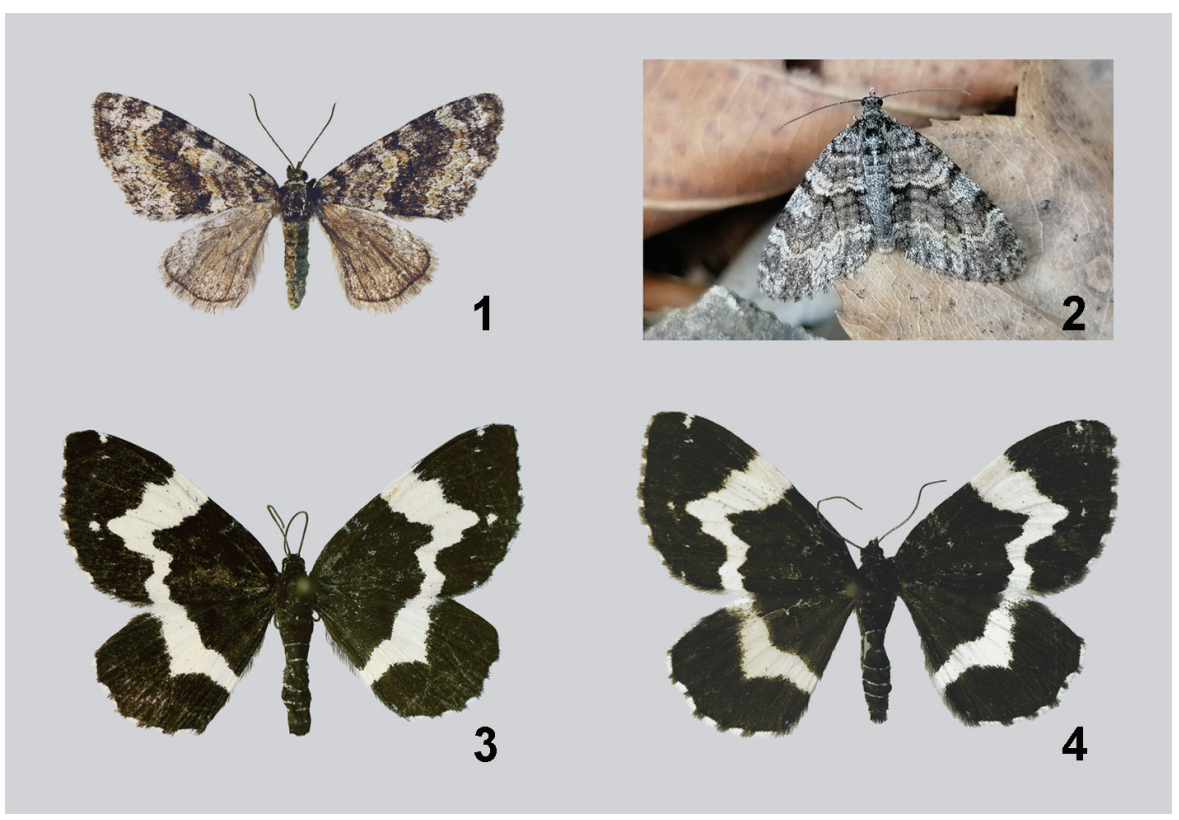

Figs 1-4. Geometrid moths. 1, 2 - Paratrichopteryx misera (Butler, 1879), female: 1 from Ryazanovka, 2 - from Vityaz (photo by Yu.A. Tshistjakov); 3, 4-Rheumaptera hecate hecate (Butler, 1878) from Telyakovsky Bay: 3 - male, 4 - female.

DISTRIBUTION. Nominative subspecies: Russia (first record), Japan (Honshu, Shikoku, Kyushu) (Nakajima \& Yazaki, 2011), and Korea (Choi, 2007). Subspecies Rh. h. matsumurai Inoue, 1977 is distributed in Russia (South Sakhalin and South Kuriles) and Japan (Hokkaido) (Nakajima \& Yazaki, 2011).

REMARKS. The Russian records are located about $140 \mathrm{~km}$ north-east from the nearest known locality of the species in North Korea (province North Khamgen, in the vicinity of Kumgang, $15 \mathrm{~km} \mathrm{NW}$ of Chondjin) (Tóth et al., 2018). Larval host plants recorded in Japan are different Ericaceae (Elliottia paniculata, Rhododendron multiflorum, Rhododendron molle, Vaccinium vitis-idaea) and Betula platyphylla (Betulaceae) (Nakajima \& Yazaki, 2011), in Korea - Rhododendron schlippenbachii (Ericaceae) (Kim et al., 2016); in the thickets of the latter, the moths were caught on the Sukhanovsky Ridge and at the Telyakovsky Bay in Russia. 


\section{DISCUSSION}

Geometrid moths, in comparison with other large families of Macrolepidoptera, are mostly conservative to their habitats and possess low migratory activity, which made this family highly convenient for biogeography studies (Holloway, 1986; Beljaev, 2011). Considering these properties, the finding of $R h$. hecate and P. misera could indicate presence of native populations of these species in the Russian Far East. Collecting history of Rh. hecate suggests it may be native for explored area at least from end of XX century. This species was unlikely missed earlier due to its bright wing patterns and diurnal activity. But most of the specimens have been collected in less visited locations. Absence of records of $R h$. hecate after 2004 is probably the result of lack of collecting of geometrids during the flight of this species in their habitats. As for P. misera, this rare and outwardly similar to common and simultaneously flying Esakiopteryx volitans (Butler, 1878) could be unnoticed earlier. However, unambiguous conclusion whether these species are long-lived inhabitants of this area in Russia or invaded recently is problematic because of highly insufficient entomological studies in Khasan District in XX century. Nevertheless, the discussed finds of Rh. hecate and P. misera in the Russian Far East correspond to the current global warming trend.

\section{ACKNOWLEDGEMENTS}

The author is thankful to Dr. M.Yu. Proshchalykin (Vladivostok) for donation of the specimen of Rh. hecate, to Dr. Yu.A. Tshistjakov (Vladivostok) for providing the photo of P. misera, and to Dr. M.G. Ponomarenko (Vladivostok) for continued collaboration in field research.

\section{REFERENCES}

Beljaev, E.A. 2011. Fauna and chorology of geometrid moths (Lepidoptera, Geometridae) of the Russian Far East. P. 158-183. In: Lelej A.S. (Ed.). Key to the insects of Russian Far East. Additional volume. Analysis of fauna and general reference titles. Dalnauka, Vladivostok. [In Russian]

Beljaev, E.A. 2016. Fam. Geometridae - Pyadenitzi. P. 518-666. In: Lelej A.S. (Ed.). Annotated catalogue of the insects of Russian Far East. Vol. 2. Lepidoptera. Dalnauka, Vladivostok. [In Russian]

Butler, A.G. 1878. Descriptions of new species of Heterocera from Japan. Part III. Geometrites. The Annals and magazine of natural history; zoology, botany, and geology, (5) 1: 440 452. DOI: https://doi.org/10.1080/00222937808682362

Butler, A.G. 1879. Descriptions of new species of Heterocera from Japan. Annals and magazine of natural history, including zoology, botany, and geology, (5) 4: 349-457. DOI: https://doi.org/10.1080/00222937908679847

Choi, S.-W. 2007. Taxonomic study of the genus Trichopteryx Hübner (Lepidoptera: Geometridae) in Korea. Entomological Research, 37: 46-53. DOI: https://doi.org/ 10.1111/j.1748-5967.2007.00052.x 
Dubatolov, V.V. 2021. First record of noctuid moth Callopistria aethiops Butler, 1878 (Lepidoptera: Noctuidae) from Southern Primorye as an example of the East Asian species penetrating in Russian fauna. Far Eastern Entomologist, 429: 8-11. DOI: https://doi.org/10.25221/fee.429.2

Hashimoto, S. 2021. Taxonomic study of the Japanese Trichopterygini (Lepidoptera: Geometridae: Larentiinae), with a proposal of a new tribe Heterophlebini. Japanese Journal of Systematic Entomology, Monograhic Series, 6: 1-146. DOI: https://doi.org/ 10.5281/zenodo.4731196

Holloway, J.D. 1986. Origins of Lepidopteran Faunas in high mountains of the Indo-Australian tropics P. 533-556. In: Vuilleumier F. \& Monasterio M. (Eds.). High Altitude Tropical Biogeography. Oxford University Press, New York.

Kim, S.-S., Choi, S.-W., Sohn, J.Ch., Kim, T. \& Lee, B.-W. 2016. The Geometrid moths of Korea (Lepidoptera: Geometridae). Junghaengsa, Seoul. 499 pp.

Koshkin, E.S., Bezborodov, V.G. \& Kuzmin, A.A. 2021. Range dynamics of some nemoral species of Lepidoptera in the Russian Far East due to climate change. Ecologica Montenegrina, 45: 62-71. DOI: https://doi.org/10.37828/em.2021.45.10

Nakajima, H. \&Yazaki, K. 2011. Larentiinae. P. 68-84, 248-316. In: Kishida Y. (Ed.). The Standard of Moths in Japan I. Callidulidae, Epicopeiidae, Drepanidae, Uraniidae, Geometridae, Lasiocampidae, Bombycidae, Saturniidae, Sphingidae. Gakken Education Publishing, Tokyo.

Tóth, B., Katona, Ge. \& Bálint Z. 2018. Data of Geometridae (Lepidoptera) from the Korean Peninsula in the collections of the Hungarian Natural History Museum - subfamily Larentiinae. Folia Entomologica Hungarica, 79: 127-161. DOI: https://doi.org/10.17112/ FoliaEntHung. 2018.79.127

Ustjuzhanin, P.Ya., Kovtunovich, V.N., Dubatolov, V.V. \& Streltzov A.N. 2021. First record of the genus Nippoptilia Matsumura (Lepidoptera: Pterophoridae) from Russia. Far Eastern Entomologist, 438: 13-15. DOI: https://doi.org/10.25221/fee.438.3 